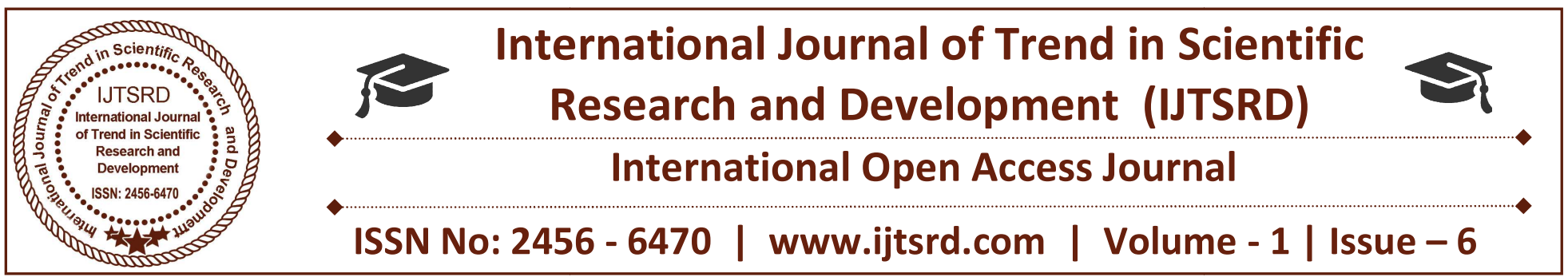

\title{
Risk in Internet Banking: A Theoretical Approach
}

\author{
Dr. Anoop K. K \\ Assistant Professor, School of Arts and Sciences, \\ Amrita University, Kochi Campus
}

\begin{abstract}
Internet banking enables customers to do basic banking functions through online. It helps the customer to save time and effort. Introduction of technology brought a new face for banking industry that gives everything by a click. Risk plays crucial role in the development of banking system in our country. It is evident from the past studies; there are different kinds of risk associated with internet banking.
\end{abstract}

This study examines the various types of internetbanking risks and the risk management methods employed in mitigating these risks. This study will explain more on various aspects of internet banking risks such as strategic risk, transaction risk, compliance risk, reputation risk, information security risk, credit risk, interest rate risk and liquidity risk, with the risk management methods. These risks should be recognized, attended to and controlled by banking establishments in a careful approach according to the basic attributes and challenges of internet banking services.

Keywords: Internet banking, Risk in internet banking, Types of internet banking risk, challenges of internet banking, Risk Management principles.

\section{JEL Classifications: $O$}

\section{INTRODUCTION}

The advent of technology in the banking workplace made a drastic change in the way of doing banking business. Now banking is virtual it means the provision of banking and banking related activities through the web. The customers are not required to visit any physical branch; they can do all the banking activities with the help of a computer and internet connection. According to the study of Forcht and Wex (1996), "internet provides opportunities for businesses to increase their customer base reduce transaction costs and sell their products globally". Durkin and Howcraft (2003) stated that, in the banking industry, the use of the internet has been recognized as an effective relationship marketing tool. Now days banks provides various internet banking services to the customers such as balance enquiry, viewing account summary, recharge of mobile phones, etc... all these facilities brought the customers in to one roof. In this digital era, internet banking plays a vital role in the development of banking sector in our country. It is a kind financial service developed by the intersection of conventional banking system with the emergence of internet system. In simple terms, internet banking means conducting banking electronically. Innovations in the field of banking, information and telecommunication technologies have drastically changed the structure of the overall financial system and particularly of the banking system by lowering the transaction costs and reducing asymmetric information (Katri et. al 2002).

Hence the main motto of this study is to identify the various kinds of risks associated with the internet banking and also study about the management of risk at the banking workplace.

\section{SIGNIFICANCE OF THE STUDY}

In this age of digital divide everything is possible by a click. Internet banking is one among them. Now day's technology plays a vital role in the overall development of an economy. It made considerable 
change in the area of banking sector also. Earlier bank requires number of ledgers and books to record the transactions. When technology becomes the part of the system, everything is getting ready with seconds. Internet banking offers wide variety of services to the customers. The facilities available in internet banking help the customers to do the transaction quick and reliable manner.

Hence the purpose of present study is to list out the various kinds of risk associated with inter banking. The outcome of this study will give some meaningful inputs to the banking sector that facilitates banks to improve their performance.

\section{RESEARCH METHODOLOGY}

Research methodology is considered to be the core area of any kind of research. Without proper strategic plan it is very difficult to carry the research in front. So choosing methodology for the work is a careful task. The success of any research work mostly depends on its methodology.

In this study the researcher reviewed extensively large number of published articles in the area of banking and finance. The study mainly based on secondary data which are collected from different sources like journals, theses, books etc.... the study also gathered some valuable opinions from the bank officials. So the present study used information's from various mix of sources.

\section{RESEARCH QUESTIONS}

In this research the researcher tries to find the answer for the following questions.

1. What are the different kinds of risk in internet banking?

\section{How bank manage the risk in internet banking?}

\section{LITRETATURE REVIEW}

\section{Internet banking risk:}

The study conducted by RupaRegeNitsure (2003) found that e-banking has the potential to transform the banking business as it lower transaction and delivery cost. The study observes that low penetration of information and telecommunication technology facing in realizing advantages of e-banking initiatives. The outcome of the study concludes that, the birth of 'digital divide' makes a meaningful distinction between the rich and poor from the financial system. The empirical evidence shows that, richer countries possess higher concentration of internet users in comparison with poorer countries. (Hawkins 2002).

JayashreeChavan (2013) claims that, the major reasons for the poor growth of internet banking in India is security concerns, preference for face to face transactions by the customers, lack of knowledge about the use of online banking, difficult to operate and lack of facility in the current bank account. In this study, the researcher observed that, the major challenges of internet banking in India is, unable to adopt global technology to local environment, confidentiality and lack of integrity and authentication.

Majidkarimzadeh (2012) opined that, infrastructural barriers, knowledge barriers, legal and security issues, social and cultural barriers, economic factors and banking management issues are the major obstacles for the growth of internet banking in India. The study reveals that, the major issues with internet banking is relate to socio-cultural dimensions.

N Jamaludhin (2013) conducted a study on the topic "E-banking challenges and opportunities in India" in this study the researcher try to understand about the experience of offering banking transactions through electronic delivery channels. The study reveals that internet banking becoming immensely popular in the country. The fall in the price of internet and mobile charges and the decline in the price of pc and lap top encourage the boom in e-banking in our country.

Arun Ingle \&Rajendra Singh Pardeshi (2012) studied about the challenges and opportunities of internet banking in Indian scenario. The study discovered that internet banking offers lot of benefits to the customers as well as the banks. Apart from the benefits, most of the customers do not prefer banking through online because of security and technological problems. The major recommendation of the study was the bank should take proper steps to educate the customers on the importance of internet banking.

FrimpongTwum et al... (2012) studied on internet banking security strategy and customer trust. The study investigates about the adoption and nonadoption of internet banking among the customers in relation with security and trust aspects. It indicates that, some customers having a feel that internet banking is secure but in other side another group 
opined that internet banking is not secure. The study, also found that customer perception of internet banking security is significantly related to usage and is significantly affected by trust of the system and trust of the provider. The study concludes that customer perception of internet banking security is influenced by customers' trust of the bank and the internet system and this subsequently influences usage intentions.

AsliyukselMermod (2011) in his study, found that there are various kinds of risk associated with internet banking such as strategic risk, operational and transactional risk, compliance risk, reputational risk, information security risk, credit risk, interest rate risk, liquidity risk, price risk and foreign exchange risk. The main objective of his study was to investigate the attitudes and expectations of internet banking users. The study made a meaningful conclusion that, usage of internet banking is significantly related with the education level of the customers. The study also found that, the most preferred application of internet banking is fund transfer.

G.S Aneeshkumar et al... (2013) conducted a study titled "Risks and Trust in Internet Banking: Sample Evidence from Pathanamthitta District, Kerala". The outcome of the study indicates that, most preferred channel of internet banking among the customers is balance enquiry followed by recharge of mobile phones etc...another findings of the study is that, there is no significant statistical difference between the males and females towards the risk but in the case of trust there is a significant relationship among the males and females.

Krishna A. Goyal \& Vijay Joshi (2012) made an attempt to study the challenges and opportunities for the Indian banking industry. The study involves certain variables like, rural market, transparency, customer expectations, management of risks, and growth in banking sector, human factor, global banking, environmental concern, social, ethical issues, employee, and stomer retentions. Banks are striving to combat the competition. The competition from global banks and technological innovation has compelled the banks to rethink their policies and strategies

Vishal Goyal, U.S.Pandey \& Sanjay Batra (2012) in his study identified the challenges and security concern of m-banking in India. The study found that, there are many barriers for the adoption of m-banking in India. It mainly includes the regulations of RBI associated with the m-banking, rupee transactions, existing account holders, and demographic challenges. All these factors restrict the growth of mbanking in India.

Dinesh B. Raghuwanshi(2012) their study concerned with the Retail Banking In India Challenges and Opportunities. The study found that, Increase in purchasing power of the younger population would give an immense opportunity. And at the same time, the challenges are equally daunting the growth of retail banking.

\section{RESEARCH GAP}

From the analysis of extensive literature review on internet banking it has been concluded that very few studies had been conducted on the subject matter in Indian scenario. But if we look at global level there a many studies conducted in the internet banking context. It indicates there is gap in between Indian and global internet banking scenario. This led researcher to carry research on this topic.

\section{THEORETICAL APPROACH}

\section{Internet banking:}

Internet banking plays a vital role in the development of Indian banking industry. Internet banking enables the customer to perform the basic banking transactions through internet without visiting the physical branch. It offers benefits to both customers as well as the bank staff. For the customers, it offers $24 * 7$ days week services to the customers without any geographical restriction and it also save the customers money and effort. It provides banking convenience to the customers. Internet banking offers a bundle of benefits to the bank like, saving the cost of establishing new buildings, reduce the job burden etc.

\section{Risk in internet banking:}

As per the directions of Basel committee report, the major type of risk associated with banking industry can be broadly classified in to eight main categories namely; credit, interest rate, market, liquidity, operational, reputation, legal and strategic. The report states that along with the benefits of internet banking there are some drawbacks with internet banking.

In the year 1999, a special commission (EBA) was appointed for the purpose of development in this area. 
The commission was formed with the joint effort of central bank and bank supervisors. The Electronic banking group has identified some risks which are very close to the online banking environment.

\section{Types of internet banking risk:}

$>$ Strategic risk

$>$ Operational risk

$>$ Compliance risk

$>$ Informational security risk

$>$ Credit risk

$>$ Interest rate risk

$>$ Reputational risk

$>$ Liquidity risk

\section{$>\quad$ Strategic Risk:}

Strategic risk is the most significant form of risk in internet banking. It mainly affects the earnings and capital of the bank. The board of directors and senior management has the authority and responsibility to take strategic decisions in the organization. It is the duty of the board and senior management officials to design a suitable business strategy and to frame a plan for the improvement of e-banking system. But in real practice, most of the bank officials do not have a clear idea about internet banking security. The lack of planning, inadequate cost-benefit analysis, poor services and delivery can increase a bank's strategic risk.

\section{$>\quad$ Operational Risk:}

Operational risk is the most common type of risk in internet banking. The term operational risk also known as transaction risk/security risk/IT risk affects bank's earnings and capital. The risk is usually arising from fraud, negligence and error. The major challenge in this area, it is difficult to predict the volume of the customers that the banks want to obtain. Complexity in banking of various products, process of banking, wide range of services, adoption innovative technologies may the reason to increase the operational risk.

\section{Compliance Risk:}

The compliance risk is a major type of risk in online banking environment that has an effect on earnings or capital arising from violence of laws, rules and ethical standards governing electronic banking. Compliance risk may lead to damage the banks goodwill, loss of money and reduced new business opportunity. This kind of risk also occur, when bank share the customers data without their consent or approval.

\section{$>$ Reputational Risk:}

This type of risk is mainly concerned with the banks goodwill. It creates a bad impact in the mind of customer about the bank. This is caused by when bank do not deliver the services to the customers expected level. The limited geographical coverage, buggy software, unattractive bank website may create a bad picture in the mind of customer.

\section{Informational Security Risk:}

Information security risk is the risk that has negative impact on earnings and capital arising out of poor information security system, attack of hackers and crackers, viruses, data theft and unauthorized access of personal information.

\section{Credit Risk:}

Credit risk is occurring when customer is not in position to meet his financial obligations. Internet banking provides loan facility to the customers. But it is difficult to verify the real identity of the customer, if they plan to provide credit through internet banking.

\section{Interest Rate Risk:}

Interest rate risk is a form of risk in internet banking context. This is mainly occur due to fluctuations in interest rates

\section{Liquidity Risk:}

Liquidity risk arises when bank is unable to meet its obligations. Internet banking can increase asset and deposit volatility particularly from customers who can move easily their actual accounts to other accounts. 


\section{CONCEPTUAL MODEL FOR INTERNET BANKING RISK:}

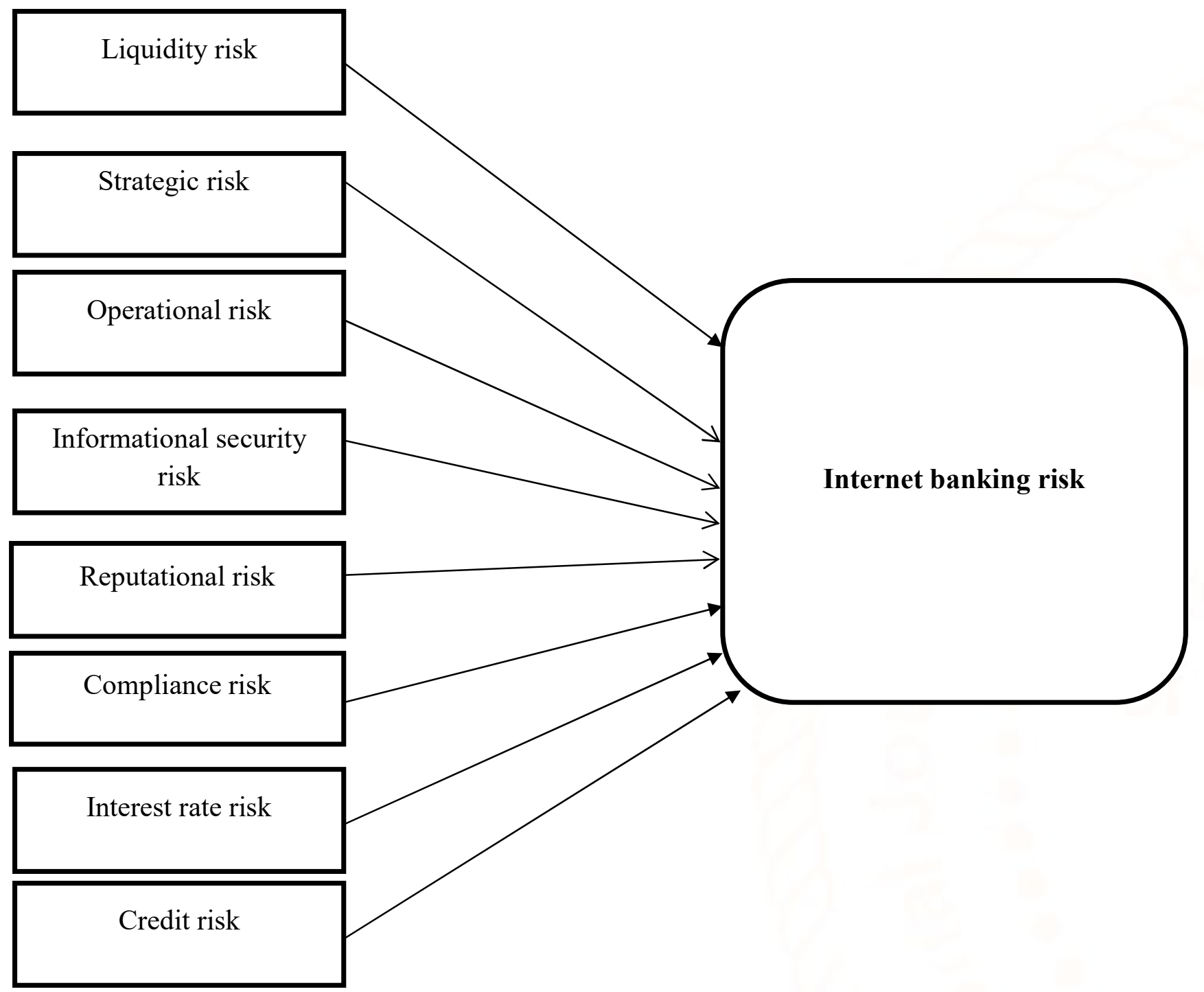

Source: Studies conducted by previous researchers

\section{FINDINGS AND CONCLUSION}

To conclude, just as is true for any other sector, banking and finance industry where technology is effectively used, e-banking is becoming increasingly widespread.From the research we could say that, internet banking has a wider scope in today's banking scenario. It provides various benefits to the customers as well as the banks.

In this research, the researcher identified different type of risk associated with internet banking. The study examines how these risk affect internet banking context. Here the researcher used conceptual model to show different kind of risk and its impact in internet banking. So the researcher takes care in the evaluation of risk of internet banking.

The study mainly founds that the factors like, convenience, ease of use, cost effective had a positive influence on the usage internet banking in India. This is the main reason for the adoption of internet banking among the customers. At the same time, internet banking has many negatives. This is the main reason for the slow growth of internet banking in India. Factors like privacy, trust, social and cultural issues etc...are the major challenges faced by internet banking in India. 
It is widely recommended that banks that carry out online banking clearly explain the privacy rule and communicate it to their clients. Banks can also make use of materials like Vendor Oversight, Assignment Sheet and Excel Spreadsheet for Risk Assessment for Policies amongst so many created from a range of data resources to carry out data safekeeping.

\section{BIBLIOGRAPHY}

1) Gbadeyan, R. A., \& Akinyosoye-Gbonda, O. O. (2011). Customers ' Preference for E-Banking Services: A Case Study of Selected Banks in Sierra Leone. Australian Journal of Business and Management Research, 1(4), 108-116.

2) Hair, J. F. Jr., Black, W.C., Babin, B.J. \& Anderson, R.E. (2013). Multivariate Data Analysis: A Global Perspective (7/e), Pearson Education: New Delhi

3) Heskett, J. L., Sasser, W. E., \& Schlesinger, L. A. (1997). The service profit chain. New York, NY: The Free Press

4) Jun, M., \& Cai, S. (2001). The key determinants of Internet banking service quality: a content analysis. International Journal of Bank Marketing, 19, 276-291.
5) Kaiser, H.F. (1974). An index of factorial simplicity. Psychometrika, 39, 31-36.

6) Kamakodi, N., \& Khan, (2008). Customer Expectations and Service Level in E-Banking Era: An Empirical Study. ICFAI University Journal of bank management, 7(4).

7) Margaret, M., \& Mauchi, N. (2013). SocioDemographic Factors Influencing Adoption of Internet Banking in Zimbabwe. Journal of Sustainable Development in Africa, 15(8), 145154.

8) Mirza, A.P., Wallstrom, A., \& Mirza, O.P. (2009). Adoption of internet banking by Iranian consumers: An empirical investigation. Journal of Applied Sciences, 9(4) 2567-2575.

9) Polasik, M., \& Wisniewski, T. P. (2009). Empirical analysis of internet banking adoption in Poland. International Journal of Bank Marketing, 27(1), 32-52.

10) Qayyum, F., \& ALI, H. (2012). Factors determining customers' adoption of internet banking: A Quantitative Study of Swedish Customers. Mälardalen University. 